\begin{tabular}{|c|c|c|c|c|}
\hline Prosiding & e ISSN : 2581- & & & \\
Penelitian \& & Vol 6, No: 2 & Hal: $123-180$ & Juli 2019 \\
$\begin{array}{c}\text { Pengabdian } \\
\text { Kepada }\end{array}$ & $\begin{array}{c}\text { 1126 p ISSN : } \\
\text { Masyarakat }\end{array}$ & 2442-448X & & \\
\hline
\end{tabular}

\title{
SISTEM BUDGETING PADA BAGIAN ANGGARAN DI BALAI PEMASYARAKATAN (BAPAS) KELAS I BANDUNG
}

\author{
Aida Nurbaiti ${ }^{1}$, Cecep ${ }^{2}$, Intania Ihsani ${ }^{3}$, Soni Akhmad Nulqakim ${ }^{4}$ \\ ${ }^{1,2,3}$ Program Studi Kesejahteraan Sosial, Fakultas IImu Sosial dan IImu Politik, \\ Universitas Padjadjaran
}

aida16001@unpad.ac.id, intania16001@mail.unpad.ac.id, cecep16002@mail.unpad.ac.id, soni.nulhaqim@unpad.ac.id

\begin{abstract}
ABSTRAK
Dalam memberikan pelayanan kepada masyarakat, Balai Pemasyarakatan (BAPAS) Kelas I Bandung melaksanakan fungsi budgeting (penganggaran) dalam implementasi programnya. Penelitian ini bertujuan untuk mengetahui alur penganggaran, pengalokasian dana, laporan keuangan, serta aplikasi yang digunakan oleh Balai Pemasyarakatan (BAPAS) Kelas I Bandung. Riset ini menggunakan jenis penelitian deskriptif, pendekatan kualitatif serta teknik pengumpulan data: wawancara, observasi dan dokumentasi. Temuan penelitian ini yaitu alur penganggaran Bapas diajukan secara bertingkat mulai dari Bapas, Kantor Wilayah Kementerian Hukum dan Ham Bandung, Kantor Wilayah Jawa Barat, dan Kantor Wilayah Pusat di Jakarta, dan Bappenas, serta Kementerian Keuangan. Pengalokasian dana digunakan untuk Program Pembinaan dan Penyelenggaraan Pemasyarakatan, untuk menghasilkan layanan yang baik. Laporan keuangan Bapas menjelaskan tentang jumlah total dana yang diterima dan dilengkapi dengan sejumlah Kegiatan beserta jumah biayanya sesuai dengan tahun anggaran. Apikasi yang digunakan meliputi aplikasi RKA-KL, SAIBA, GPP dan SAS.
\end{abstract}

Kata kunci: Penganggaran, Keuangan, BAPAS

\section{ABSTRACT}

In providing services to the community, Balai Pemasyarakatan (BAPAS) Kelas I Bandung carries out the budgeting function in its program implementation. This study aims to determine the flow of budgeting, allocation of funds, financial statements, and applications by Balai Pemasyarakatan Kelas I Bandung (BAPAS). This research uses descriptive research, qualitative approaches and data collection techniques: interviews, observation and documentation. The findings of this study are the Bapas budgeting flow proposed in stages starting from Bapas, Bandung Regional Office of the Ministry of Law and Ham, West Java Regional Office, Central Regional Office in Jakarta, Bappenas, and the Finance Ministry. The allocation of funds is used for the Guidance and Implementation of Correctional Programs, to produce good services. The Bapas financial report explains the total amount of funds received and completed with a number of activities along with the amount of the costs according to the fiscal year. The applications used include the application of RKA-KL, SAIBA, GPP and SAS.

Keywords: Budgeting, Finance, BAPAS 


\begin{tabular}{|c|c|c|c|c|}
\hline Prosiding & ISSN : 2581- & Vol 6, No: 2 & Hal: $123-180$ & Juli 2019 \\
$\begin{array}{c}\text { Penelitian \& } \\
\text { Pengabdian }\end{array}$ & 1126 p ISSN: & 2442-448X & & \\
Kepada & & & \\
Masyarakat & & & \\
\hline
\end{tabular}

\section{PENDAHULUAN}

Pemasyarakatan adalah suatu kegiatan untuk melakukan pembinaan kepada Warga Binaan Pemasyarakatan berdasarkan sistem, kelembagaan, dan cara pembinaan yang merupakan bagian akhir dari sistem pemidanaan dalam tata peradilan pidana. Kegiatan Pelaksanaan pembinaan dan bimbingan Warga Binaan Pemasyarakatan dilakukan di BAPAS (Balai Pemasyarakatan). Balai Pemasyarakatan adalah unit pelaksana teknis direktorat jenderal pemasyarakatan yang berada dibawah dan bertanggung jawab langsung kepada kantor wilayah kementerian Hukum dan Hak Asasi Manusia, yang terletak di Jl. Ibrahim Adjie No.431, Kb. Kangkung, Kiaracondong, Kota Bandung, Jawa Barat 40284.

Balai Pemasyarakatan Kelas I Bandung merupakan pranata atau satuan kerja dalam lingkungan Kantor Wilayah Kementerian Hukum dan HAM Jawa Barat yang ditugaskan melakukan pembimbingan terhadap klien sampai suatu batas kemampuan yakni dapat menghadapi dan mengatasi permasalahannya secara mandiri. Balai Pemasyarakatan Kelas I Bandung melaksanakan pembinaan, bimbingan dan pengawasan terhadap klien pemasyarakatan di luar lembaga pemasyarakatan agar klien dapat berintegrasi dengan baik di masyarakat sesuai dengan nilai dan norma yang berlaku di masyarakat.

Dalam memberikan pelayanan kepada masyarakat, Balai Pemasyarakatan Kelas I Bandung sebagai suatu lembaga yang harus bisa menggunakan fungsi menajemen yang sesuai agar pelayanan sosial yang diberikan secara maksimal dalam memenuhi kebutuhan masyarakat secara luas. Fungsi manajemen tersebut mencakup aspek Planning, Organizing, Human Resources Development, Fundraising dan Information System.
Berdasarkan kelima aspek ogranisasi pelayanan sosial tersebut saling berkaitan satu dengan yang lainnya, salah satu aspek yang terkait untuk mendukung kebutuhan dan menjalankan segala kegiatan organisai pelayanan sosial yaitu pada aspek budgeting (penganngaran). Menurut Rachmasari dkk (2016), fundraising merupakan salah satu aspek penting dalam mempertahankan suatu organisasi pelayanan sosial. Fundraising mencakup fungsi budgeting dan penggalangan dana untuk melaksanakan aktifitas pemberian layanan sosial. Oleh karena itu, dibutuhkan pemahaman dan strategi-strategi bagi organisasi pelayanan sosial untuk dapat menjalankan fungsi budgeting organisasinya agar organisasi tidak terhambat dalam pelaksanaan kegiatannya.

Aspek budgeting memang sangat penting dalam kelembagaan terutama bagi, salah satunya yaitu Balai Pemasyarakatan Kelas I Bandung. Karena BAPAS merupakan salah satu lembaga pemerintahan, maka seluruh anggaran didapat dari pemerintah pusat. Pencairan dana tersebut dilakukan melalui KPPN $\begin{array}{llll}\text { Bandung } & 1 & \text { (Kantor Pelayanan }\end{array}$ Perbendaharaan Negara). Untuk mengajukan anggaran dana dilakukan satu tahun sebelumnya melalui aplikasi khusus yang disebut RKAL (Rencana Kerja Anggaran Kementerian/Lembaga).

\section{KAJIAN PUSTAKA \\ Penganggaran}

Menurut National Committee on Governmental Accounting (NCGA), anggaran adalah rencana operasi keuangan yang mencakup estimasi pengeluaran yang diusulkan dan sumber pendapatan yang diharapkan untuk membiayainya dalam periode waktu tertentu. Budget biasanya termasuk aspek finansial dan non finansial dari suatu rencana dan membantu sebagai blueprint 


\begin{tabular}{|c|c|c|c|c|}
\hline Prosiding & e ISSN : 2581- & & & \\
Penelitian \& & Vol 6, No: 2 & Hal: $123-180$ & Juli 2019 \\
$\begin{array}{c}\text { Pengabdian } \\
\text { Kepada }\end{array}$ & 1126 p ISSN : & V442-448X & & \\
Masyarakat & & & \\
\hline
\end{tabular}

bagi perusahaan untuk melakukan pekerjaan di masa depan.

Dalam Pasal 1 Undang-Undang Nomor 17 Tahun 2003 dijelaskan pengertian Keuangan Negara yaitu semua hak dan kewajiban yang dapat dinilai dengan uang, serta segala sesuatu baik berupa uang maupun barang yang dapat dijadikan milik negara berhubung dengan pelaksanaan hak dan kewajiban tersebut. Penganggaran di sektor pemerintahan merupakan suatu proses yang kompleks dan panjang serta tidak dapat dilepaskan dari sektor politis. Kompleksitas disebabkan karena belum adanya kesempatan yang dapat diterima semua pihak tentang bagaimana pengalokasian sumber dana pemerintah secara tertib.

Terdapat berbagai definisi tentang arti budgeting, namun secara budgeting (penganggaran) dapat diartikan sebagai suatu cara atau metode yang sistematis untuk mengalokasikan sumber-sumber daya keuangan. Sedangkan budget (anggaran) diartikan secara singkat oleh Brimson dan Antos (1994) sebagai rencana yang dituangkan dalam angkaangka financial. Berkaitan dengan organisasi pemerintahan, penganggaran berarti proses pengalokasian sumber daya keuangan negara yang terbatas untuk digunakan membiayai pengeluaran oleh unit pemerintahan (kementerian dan lembaga sebagai pengguna anggaran).

\section{Anggaran Negara}

Anggaran negara merupakan rencana keuangan pemerintah dalam suatu waktu tertentu yang biasanya dalam satu tahun mendatang. Dalam hal ini, satu pihak memuat jumlah pengeluaran setinggi-tingginya untuk membiayai tugastugas negara di segala bidang dan di lain pihak memuat jumlah penerimaan negara yang diperkirakan dapat menutup pengeluaran tersebut dalam periode yang sama (Dedi Nordiawan, Iswahyudi Sondi Putra dan Maufidah Rahmawati, 2007).

Pengertian lainnya pun dijelaskan oleh Mahmudi tahun 2007 sebagai berikut:
1. Anggaran merupakan pernyataan mengenai estimasi kinerja pemerintah yang hendak dicapai selama periode waktu tertentu yang dinyatakan dalam ukuran finansial (rupiah)

2. Penyusunan anggaran negara adalah suatu proses politik, penganggaran merupakan proses atau metode untuk mempersiapkan suatu anggaran dengan tahap yang rumit dan mengandung nuansa politik yang sangat kental karena memerlukan pembahasan dan pengesahan dari wakil rakyat di parlemen yang terdiri dari berbagai utusan partai politik.

3. Berbeda dengan anggaran pada sektor swasta, dimana anggaran merupakan bagian dari rahasia perusahaan yang tertutup untuk public, sebaliknya anggaran negara justru harus dikonfirmasikan kepada public untuk diberi masukan dan kritik.

4. Anggaran negara merupakan instrument akuntabilitas atas pengelolaan dana public dan pelaksanaan program-program yang dibiayai dengan uang public. Proses penganggaran dimulai ketika perencanaan astategi dan perumusan strategi telah diselesaikan.

5. Tahap penganggaran menjadi sangat penting karena anggaran yang tidak efektif dan tidak berorientasi pada kinerja akan dapat menggagalkan perencanaan yang sudah disusun.

Penganggaran memiliki tiga tujuan utama yang saling terkait, yaitu stabilitas fiscal makro, alokasi sumber daya sesuai prioritas dan pemanfaatan anggaran secara efektif dan efisien. Sebagai instrument kebijakan ekonomi anggaran berfungsi untuk mewujudkan pertumbuhan ekonomi, stabilitas ekonomi dan pemerataan pendapatan. Anggaran negara pun berfungsi sebagai alat perencanaan dan pengawasan aktivitas pemerintahan. Sebagai alat perencanaan kegiatan public, anggaran dinyatakan sebagai satuan mata uang sekaligus dapat digunakan sebagai alat pengendalian. Agar fungsi ini dapat berjalan dengan baik, maka system pencatatan atas penerimaan dan pengeluaran harus dilakukan dengan cermat dan sistematis. 


\begin{tabular}{|c|c|c|c|c|}
\hline Prosiding & e ISSN : 2581- & & & \\
Penelitian \& & Vol 6, No: 2 & Hal: $123-180$ & Juli 2019 \\
$\begin{array}{c}\text { Pengabdian } \\
\text { Kepada }\end{array}$ & 1126 p ISSN : & 2442-448X & & \\
Masyarakat & & & \\
\hline
\end{tabular}

\section{Prinsip-Prinsip Penganggaran}

Anggaran merupakan satu instrumen penting di dalam manajemen karena merupakan bagian dari fungsi manajemen. Di dunia bisnis maupun di organisasi sektor publik, termasuk pemerintah, anggaran merupakan bagian dari aktivitas penting yang dilakukan secara rutin. Dalam rangka penyusunan anggaran terdapat beberapa prinsip penganggaran yang perlu dicermati (Dedi Nordiawan, Iswahyudi Sondi Putra dan Maufidah Rahmawati tahun 2007), yaitu:

1. Transparansi dan Akuntabilitas Anggaran

APBD harus dapat menyajikan informasi yang jelas mengenai tujuan, sasaran, hasil, dan manfaat yang diperoleh masyarakat dari suatu kegiatan atau proyek yang dianggarkan. Anggota masyarakat memiliki hak dan akses yang sama untuk mengetahui proses anggaran karena menyangkut aspirasi dan kepentingan masyarakat, terutama pemenuhan kebutuhan-kebutuhan hidup masyarakat. Masyarakat juga berhak untuk menuntut pertanggungjawaban atas rencana ataupun pelaksanaan anggaran tersebut.

2. Disiplin Anggaran
Pendapatan yang direncanakan merupakan perkiraan yang terukur secara rasional yang dapat dicapai untuk setiap sumber pendapatan, sedangkan belanja yang dianggarkan pada setiap pos/pasal merupakan batas tertinggi pengeluaran belanja. Penganggaran pengeluaran harus didukung dengan adanya kepastian tersedianya penerimaan dalam jumlah yang cukup dan tidak dibenarkan melaksanakan kegiatan yang belum/tidak tersedia anggarannya dalam APBD/ APBD-Perubahan.

3. Keadilan Anggaran
Pemerintah
daerah
wajib
mengalokasikan
penggunaan
anggarannya secara adil agar dapat dinikmati oleh seluruh kelompok masyarakat tanpa diskriminasi dalam pemberian pelayanan karena pendapatan daerah pada hakekatnya

diperoleh melalui peran serta masyarakat.

4. Efisiensi dan Efektivitas Anggaran Penyusunan anggaran hendaknya dilakukan berlandaskan asas efisiensi. Dana yang tersedia harus dimanfaatkan dengan sebaik mungkin untuk dapat menghasilkan peningkatan dan kesejahteraan maksimal untuk kepentingan masyarakat.

5. Disusun Dengan Pendekatan Kinerja APBD disusun dengan pendekatan kinerja, yaitu mengutamakan upaya pencapaian hasil kerja (output/outcome) dari perencanaan alokasi biaya atau input yang telah ditetapkan. Hasil kerjanya harus sepadan atau lebih besar dari biaya atau input yang telah ditetapkan. Selain itu harus mampu menumbuhkan profesionalisme kerja di setiap organisasi kerja yang terkait.

\section{Fungsi Penganggaran}

Suatu system penganggaran memiliki banyak fungsi dan fungsi tersebut dapat saling terkait. Secara umum fungsi penganggaran menurut Michael Granof tahun 2001, yaitu:

a. Perencanaan (planning)

Hal ini berkaitan dengan menentukan jenis, kuantitas dan kualitas jasa yang akan disediakan untuk konstituen, memperkirakan biaya atas jasa-jasa tersebut, dan menentukan bagaimana pembayaran untuk jasa tersebut.

b. Pengendalian dan pengelolaan Anggaran membantu memastikan bahwa sumber daya diperoleh dan digunakan sesuai dengan rencana.

c. Pelaporan dan evaluasi

Anggaran menjadi dasar untuk pelaporan, pengevaluasian pada akhir periode. Perbandingan realisasi dengan anggaran menunjukkan apakah mandate penerimaan dan pengeluaran sudah dilaksanakan. Selain itu, jika dikaitkan dengan tujuan organisasi, anggaran dapat memfasilitasi penilaian efisiensi dan efektivitas.

\section{Proses Penyusunan Anggaran}

Perencanaan anggaran dalam organisasi sektor public, terutama 


\begin{tabular}{|l|c|c|c|c|}
\hline Prosiding & e ISSN : 2581- & & & \\
Penelitian \& & Vol 6, No: 2 & Hal: $123-180$ & Juli 2019 \\
$\begin{array}{c}\text { Pengabdian } \\
\text { Kepada }\end{array}$ & 1126 p ISSN : & $2442-448 X$ & & \\
Masyarakat & & & \\
\hline
\end{tabular}

pemerintah merupakan sebuah proses yang cukup rumit dan mengandung muatan politis yang signifikan, anggaran bukan hanya sebuah rencana tahunan tetapi juga merupakan bentuk akuntabilitas atas pengelolaan dana public yang dibebankan kepadanya. Anggaran berbasis kinerja merupakan system perencanaan, penganggaran dan evaluasi yang menekankan pada keterkaitan antara anggaran dengan hasil yang diinginkan. Penerapan penganggaran kinerja harus dimulai dengan perencanaan kinerja, baik pada level nasional (pemerintah) amupun level instansi (kementerian atau lembaga) yang berisi komitmen tentang kinerja yang akan dihasilkan dan dijabarkan dalam programprogram serta kegiatan yang akan dilakukan.

Selanjutnya, setiap instansi menyusun kebutuhan anggaran berdasarkan program dan kegiatan yang direncanakan dengan format Rencana Kerja Anggaran Kementerian Lembaga (RKA-KL) yang selanjutnya dibahas dengan otoritas anggaran (Departemen Keuangan, Bappenas, dan DPR). RKA-KL dari keseluruhan kementerian/lembaga kemudian dihimpun dan menjadi bahan penyusunan RAPBN bagi pemerintah.

\section{Tahapan Penyusunan Anggaran}

Tahapan dalam proses penyusunan anggaran yang dikemukakan oleh R.A Supriyono adalah:

a) Memahami SWOT

Menganalisis informasi terdahulu dan perubahan lingkungan luar melalui analisis SWOT (strength, weakness, opportunities, and threats) yang dimiliki organisasi dan lingkungannya. Lingkungan luar yang dianalisis meliputi, kondisi perekonomian, persaingan, selera konsumen, kebijakan pemerintah, sosial-budaya-politikkeamanan, perkembangan teknologi. SWOT atau unit bisnis harus dikomunikasikan pada penyusun anggaran karena mempengaruhi tujuan, strategi, dan program yang mendasari anggaran yang disusunnya.

b) Memahami perumusan strategi dan perencanaan strategi

Atas dasar SWOT, menyusun perumusan strategi yaitu proses penentuan tujuan dan startegi pokok yang akan digunakan untuk mencapai tujuan tersebut. Selanjutnya disusun programprogram untuk melaksanakan startegi dalam rangka pencapaian tujuan. Tujuan, strategi, dan program harus dikomunikasikan pada para penyusun anggaran karena mendasari anggaran yang akan disusunnya.

c) Mengkomunikasikan tujuan, strategi pokok dan program

Selanjutnya, mengkomunikasikan SWOT, tujuan, strategi, dan program yang telah ditetapkan kepada komite anggaran, para manajer divisi dan para manajer dibawahnya agar mereka mengetahui dan memahami lingkungan yang akan dihadapi, tujuan yang akan dicapai, strategi pokok yang akan dilaksanakan, serta program yang mendasari anggaran yang akan disusunnya.

d) Memilih taktik, mengkoordinasi dan mengawasi operasi

Taktik merupakan cara-cara yang digunakan untuk melaksanakan program. Selanjutnya manajer departemen membuat keputusan pengoperasian yang digunakan untuk mengkoordinasi kegiatan dibawah departemennya.

e) Menyusun usulan anggaran

Setiap manajer divisi menyusun dan mengkoordinasikan penyusunan anggaran untuk bagian organisasi.

f) Menyarankan revisi usulan anggaran

Komite anggaran menyarankan revisi terhadap usulan anggaran setiap divisi agar terdapat penyelarasan dengan anggaran divisi lain dan agar sesuai dengan rencana jangka panjang dan tujuan 


\begin{tabular}{|c|c|c|c|c|}
\hline Prosiding & e ISSN : 2581- & & & \\
Penelitian \& & Vol 6, No: 2 & Hal: $123-180$ & Juli 2019 \\
$\begin{array}{c}\text { Pengabdian } \\
\text { Kepada }\end{array}$ & 1126 p ISSN : & 2442-448X & & \\
Masyarakat & & & \\
\hline
\end{tabular}

organisasi yang telah ditentukan oleh manajemen perusahaan.

g) Menyetujui revisi anggaran dan merakit menjadi anggaran perusahaan

Setelah usulan anggaran direvisi oleh setiap divisi yang bersangkutan dan revisi tersebut telah disetujui oleh komite anggaran, maka komite merakit usulan tersebut menjadi anggaran perusahaan.

h) Revisi dan pengesahan anggaran pemerintahan

Anggaran perusahaan mungkin masih memerlukan revisi sebelum disahkan oleh manajemen puncak menjadi anggaran perusahaan yang resmi. Setelah dilakukan revisi, anggaran tersebut disahkan dan didistribusikan pula ke setiap divisi dan bagian organisasi.

\section{METODE PENELITIAN}

Penelitian ini menggunakan metode deskriptif kualitatif, yaitu penelitian yang didasarkan pada pemecahan masalah berdasarkan fakta-fakta dan kenyataan yang ada di lapangan. Proses pengumpulan data dilakukan dengan wawancara terhadap pegawai BAPAS di bagian keuangan, Observasi dengan cara mempelajari dan mengamati beberapa laporan keuangan yang terdapat di BAPAS, Studi Dokumentasi, dan Studi literatur dengan mempelajari buku ataupun jurnal yang terkait dengan HSO serta budgeting.

\section{HASIL}

Budgeting merupakan suatu rencana yang disusun secara sistematis, yang meliputi seluruh kegiatan lembaga. Dari semua itu tentunya lembaga harus mengajukan anggaran yang dibutuhkan ke pusat. Adapun aplikasi yang menunjang sistem keuangan di BAPAS, sehingga memudahkan urusan keuangan lembaga.

\section{Alur Pendanaan BAPAS}

BAPAS berdiri pada tahun 1964 dengan mengadakan musyawarah bersama Dinas Kepenjaraan Indonesia di Lembang dengan merekomendasikan system kepenjaraan diubah menjadi system pemasyarakatan. Dalam system pemasyarakatan tersebut, menggunakan suatu metode pendekatan baru yang memposisikan terpidana sebagai manusia yang harus tetap dihargai harkat dan martabat sesuai dengan falsafah Pancasila. Perlakuan terhadap narapidana ditujukan untuk melahirkan sikap sadar, insaf, dan tertib dalam hidup bermasyarakat.

Adapun tugas dari BAPAS yaitu, memperlancar tugas penyidik, penuntut umum dan hakim dalam perkara anak baik di dalam maupun di luar sidang. Selanjutnya membimbing, membantu dan mengawasi anak yang berhadapan dengan hokum berdasarkan putusan pengadilan yang dapat dijatuhkan terhadap anak.

Dalam menjalankan tugas dan fungsi dalam memberikan layanan dibutuhkan adanya suatu anggaran agar program dan kegiatan dapat dijalankan secara baik. Kementerian Keuangan dalam hal ini memiliki wewenang untuk membagikan APBN kepada setiap Kementerian, yaitu pada setiap eselon 1 atau pemerintahan pusat.

Untuk system pengajuan dana di BAPAS menggunakan aplikasi yang disebut RKA-KL (Rencana Kerja Anggaran Kementerian/Lembaga) dengan melalui beberapa alur pengajuaan dan beberapa tahap. Pertama yaitu, BAPAS mengajukan dana anggaran untuk satu tahun kerja yang ditujukan ke Kantor Wilayah Kementerian Hukum dan Ham Bandung, selanjutnya Kantor Wilayah akan mengumpulkan kebutuhan anggaran di daerah Jawa Barat seperti, Bandung, Garut, Ciamis, dan Cirebon. Kebutuhan anggaran di Jawa Barat tersebut nantinya akan diajukan kembali oleh Kantor Wilayah Kementerian Hukum dan Ham Bandung ke Kantor Wilayah Pusat di Jakarta. Terakhir, kantor pusat akan mengajukan dana anggaran kebutuhan Jawa Barat ke Badan Perencanaan Pembangunan Nasional (Bapenas) dan juga Kementerian Keuangan.

\section{Penggunaan Dana}




\begin{tabular}{|c|c|c|c|c|}
\hline Prosiding & e ISSN : 2581- & & & \\
Penelitian \& & Vol 6, No: 2 & Hal: $123-180$ & Juli 2019 \\
$\begin{array}{c}\text { Pengabdian } \\
\text { Kepada }\end{array}$ & 1126 p ISSN : & 2442-448X & & \\
Masyarakat & & & \\
\hline
\end{tabular}

Pengajuan anggaran dana di BAPAS digunakan untuk Program Pembinaan dan Penyelenggaraan dengan menghasilkan output:
1. Layanan
Pembinaan
Klien

Pemasyarakatan

2. Layanan Dukungan Manajemen Satuan Kerja

3. Layanan Sarana dan Prasarana Internal

4. Layanan Perkantoran

Dalam mengajukan anggaran program melihat dari panduan yang diberikan oleh kementerian. Lalu, merencanakan kebutuhan dana dan volume dari setiap program yang akan diselenggarakan. Setelah dana diajukan, anggaran tersebut dikoreksi dan diperiksa yang nantinya akan muncul gambaran umum mengenai fiksasi dana yang akan diberikan. Jika dana yang diberikan belum memenuhi target untuk menjalankan program yang telah direncanakan, maka akan terjadi penyesuaian dan hasil fiksasi dana pun akan diberikan di akhir tahun.

\section{Laporan Keuangan BAPAS}

Pada tahun 2018, BAPAS mendapatkan anggaran dana sebesar Rp.4.398.983.000 dengan alokasi anggaran dana sebagai berikut:

Tabel.1 Rincian Kertas Kerja SATKER T.A 2018

\begin{tabular}{|c|l|c|}
\hline $\begin{array}{c}\text { No } \\
.\end{array}$ & $\begin{array}{l}\text { Program/Kegiatan/ } \\
\text { Komponen }\end{array}$ & $\begin{array}{c}\text { Jumlah } \\
\text { Biaya }\end{array}$ \\
\hline 1. & $\begin{array}{l}\text { Pelaksanaan } \\
\text { Pembimbingan }\end{array}$ & 78.246 .000 \\
\hline 2. & $\begin{array}{l}\text { Monitoring, Evaluasi } \\
\text { dan Pelaporan }\end{array}$ & 3.000 .000 \\
\hline 3. & $\begin{array}{l}\text { Rekomendasi Program } \\
\text { Pelayanan dan } \\
\text { Pembinaan } \\
\text { (Penyusunan Litmas } \\
\text { Rekomendasi Program } \\
\text { Pelayanan/Pembinaan } \\
\text { ) }\end{array}$ & 18.600 .000 \\
\hline 4. & $\begin{array}{l}\text { Penyampaian dan } \\
\text { Diskusi Program }\end{array}$ & 6.000 .000 \\
& $\begin{array}{l}\text { Pelayanan dan } \\
\text { Pembinaan dalam TPP } \\
\text { Rutan/Lapas/LPAS/LPK } \\
\text { A }\end{array}$ & \\
\hline 5. & Monitoring, Evaluasi & 13.200 .000 \\
\hline
\end{tabular}

\begin{tabular}{|c|l|r|}
\hline & dan Pelaporan & 3.880 .000 \\
\hline 6. & $\begin{array}{l}\text { Penyusunan Rencana } \\
\text { Program dan } \\
\text { Penyusunan Rencana } \\
\text { Anggaran }\end{array}$ & 4.980 .000 \\
\hline 7. & $\begin{array}{l}\text { Pelaksanaan } \\
\text { Pemantauan dan } \\
\text { Evaluasi }\end{array}$ & 6.480 .000 \\
\hline 8. & $\begin{array}{l}\text { Pengelolaan } \\
\text { Keuangan }\end{array}$ & 16.000 .000 \\
\hline 9. & $\begin{array}{l}\text { Pengelolaan Umum } \\
\text { dan Perlengkapan }\end{array}$ & 1.000 .000 .0 \\
\hline 10. & $\begin{array}{l}\text { Pengaduan } \\
\text { Kendaraan Bermotor }\end{array}$ \\
\hline 11. & $\begin{array}{l}\text { Pengadaan Perangkat } \\
\text { Pengolah Data dan } \\
\text { Komunikasi }\end{array}$ & 320.000 .000 \\
\hline 12. & $\begin{array}{l}\text { Gaji dan Tunjangan } \\
\text { 13. }\end{array}$ & $\begin{array}{l}\text { Operasional dan } \\
\text { Pemeliharaan Kantor }\end{array}$ \\
\hline
\end{tabular}

Sumber : Laporan Keuangan Bapas Kelas 1 Bandung Tahun 2018

Sedangkan di tahun 2019 mendapatkan anggaran sebesar Rp. 5.787.970.000 dengan rincian sebagai berikut:

Tabel.2 Rincian Kertas Kerja SATKER T.A 2019

\begin{tabular}{|c|l|c|}
\hline No & $\begin{array}{l}\text { Program/Kegiatan/ } \\
\text { Komponen }\end{array}$ & \multicolumn{1}{|c|}{$\begin{array}{c}\text { Jumlah } \\
\text { Biaya }\end{array}$} \\
\hline 1. & $\begin{array}{l}\text { Sidang Tim Pengamat } \\
\text { Pemasyarakatan }\end{array}$ & 19.200 .000 \\
\hline 2. & $\begin{array}{l}\text { Pendampingan } \\
\text { Peradilan Anak (Vol }= \\
\text { per Anak) } \\
\text { Penyusunan Litmas } \\
\text { Anak }\end{array}$ & 70.200 .000 \\
\hline 3. & $\begin{array}{l}\text { Pelaksanaan } \\
\text { Pendampingan Anak } \\
\text { (Pemeriksaan awal, } \\
\text { Diversi, Pelimpahan } \\
\text { Perkara, } \\
\text { Persidangan , } \\
\text { Pelaksanaan Putusan, } \\
\text { Penetapan } \\
\text { Pengadilan \& } \\
\text { Pemenuhan Hak } \\
\text { Anak) }\end{array}$ & \\
\hline 4. & $\begin{array}{l}\text { Monitoring, Evaluasi } \\
\text { \& Pelaporan }\end{array}$ & 34.000 .0000 \\
\hline
\end{tabular}




\begin{tabular}{|c|c|c|c|c|}
\hline Prosiding & e ISSN : 2581- & & & \\
Penelitian \& & Vol 6, No: 2 & Hal: $123-180$ & Juli 2019 \\
$\begin{array}{c}\text { Pengabdian } \\
\text { Kepada }\end{array}$ & 1126 p ISSN : & 2442-448X & & \\
Masyarakat & & & \\
\hline
\end{tabular}

\begin{tabular}{|c|c|c|}
\hline 5. & $\begin{array}{l}\text { Pembimbingan dan } \\
\text { Pengawasan oleh } \\
\text { BAPAS (Vol. Per Klien) } \\
\text { Penyusunan Litmas } \\
\text { dan Penetasan }\end{array}$ & 402.600 .00 \\
\hline 6. & $\begin{array}{l}\text { Pelaksanaan } \\
\text { Pembibingan }\end{array}$ & 158.093 .000 \\
\hline 7. & $\begin{array}{l}\text { Monitoring, Evaluasi } \\
\text { dan Pelaporan }\end{array}$ & 34.150 .000 \\
\hline 8. & $\begin{array}{l}\text { Penyususnann } \\
\text { Rencana Anggaran }\end{array}$ & 6.900 .000 \\
\hline 9. & $\begin{array}{l}\text { Pengelolaan } \\
\text { keuangan }\end{array}$ & 6.000 .000 \\
\hline 10. & $\begin{array}{l}\text { Pengelolaan } \\
\text { Kepegawaian }\end{array}$ & 51.500 .000 \\
\hline 11. & $\begin{array}{l}\text { Pelayanan Umum dan } \\
\text { Perlengkapan }\end{array}$ & 3.300 .000 \\
\hline 12. & Gaji dan Tunjangan & $\begin{array}{r}3.820 .332 .0 \\
00\end{array}$ \\
\hline 13. & $\begin{array}{l}\text { Operasional dan } \\
\text { Pemeliharaan Kantor }\end{array}$ & 571.100 .000 \\
\hline
\end{tabular}

Sumber : Laporan Keuangan Bapas Kelas 1 Bandung Tahun 2019

Sejauh ini, dana yang diterima BAPAS diberikan dari pemerintah. Namun, tidak menutup kemungkinan untuk bekerja sama dengan pihak ketiga ketika terdapat kegiatan dan program di lapangan seperti, program kemandirian dan kepribadian yang rutin diadakan oleh BAPAS.

Tugas dan fungsi keuangan di BAPAS, yaitu:

- Membuat/mengusulkan RKA-KL

- Membuat/mengusulkan gaji karyawan

- Melaksanakan/mengurus anggaran rutin rumah tangga kantor

- Membuat/mengusulkan uang honorarium

- Melaporkan keadaan kas rutin

- Melaporkan pembagian gaji pegawai

- Membuat laporan pertanggung jawaban keuangan

Aplikasi Penunjang Kinerja

Dalam menjalankan tugas dan fungsi keuangan tersebut, terdapat beberapa aplikasi yang digunakan, yaitu:

1. RKA-KL (Rencana Kerja Anggaran Kementerian/Lembaga)

Rencana Kerja dan Anggaran Kementerian Negara/Lembaga (RKA-KL) merupakan dokumen perencanaan dan penganggaran yang berisi program dan kegiatan suatu Kementerian Negara/Lembaga dan sebagai penjabaran dari Rencana Kerja Pemerintah dan Rencana Kerja Kementerian Negara/Lembaga yang bersangkutan dalam satu tahun anggaran serta anggaran yang diperlukan untuk melaksanakannya.

2. SAIBA (Sistem Akuntansi Berbasis Akrual)

Laporan keuangan yang dihasilkan dari penerapan basis akrual dimaksudkan untuk memberikan informasi yang lebih komprehensif dan lebih baik bagi para pemangku kepentingan baik para pengguna laporan keuangan dibandingkan dengan basis kas menuju akrual yang selama ini dianut.

3. GPP (Gaji PNS Pusat)

Menurut Yunizar (2010:1) menyatakan bahwa Aplikasi Gaji Pokok Pegawai (GPP) adalah : "Aplikasi Gaji Pokok Pegawai (GPP) merupakan aplikasi pembuat daftar gaji Pegawai Negeri Sipil (PNS) pusat, aplikasi ini dibuat oleh Direktorat Sistem Perbendaharaan sebagai salah satu direktorat dibawah naungan Direktorat Jendral Perbendaharaan. Aplikasi ini termasuk aplikasi yang multifungsi, selain membuat daftar gaji, juga menyimpan data pegawai lengkap, adapun kegunaan lain Aplikasi ini :

1. Membuat kekurangan gaji (rapel), gaji susulan, uang duka (untuk PNS yang meninggal dunia), Uang Makan dan Uang lembur

2. Mencetak KP4 (Surat Keterangan untuk menambahkan keluarga dalam gaji)

3. Mencetak Rekap SPT Tahunan pegawai

4. Mencetak Surat Keterangan Penghasilan

\section{SAS (Sistem Aplikasi Satker)}

Aplikasi SAS diluncurkan pada tahun 2015 dengan menjadikan aplikasi di tingkat satker menjadi aplikasi dengan single database agar harapan 


\begin{tabular}{|c|c|c|c|c|}
\hline Prosiding & e ISSN : 2581- & & & \\
Penelitian \& & Vol 6, No: 2 & Hal: $123-180$ & Juli 2019 \\
$\begin{array}{c}\text { Pengabdian } \\
\text { Kepada }\end{array}$ & 2426 p ISSN : & & \\
Masyarakat & & & & \\
\hline
\end{tabular}

mempermudah satker dalam pengelolaan keuangan melalui aplikasi.

\section{KESIMPULAN}

Berdasarkan hasil penelitian di Balai Pemasyarakatan (BAPAS) Kelas I Bandung, penulis menarik kesimpulan bahwa anggaran keuangan di Balai Pemasyarakatan (BAPAS) berasal dari pemerintah dengan mengikuti berbagai tahapan dan alur birokrasi keuangan yang telah ditetapkan sebelumnya. Penganggaran pun digunakan untuk kegiatan pokok BAPAS yang berupa penyelenggaraan pemasyarakatan di wilayah.

Pengajuan anggaran dana di BAPAS digunakan untuk Program Pembinaan dan Penyelenggaraan Pemasyarakatan, dengan menghasilkan output:
1. Layanan Pembinaan
Klien

Pemasyarakatan

2. Layanan Dukungan Manajemen Satuan Kerja

3. Layanan Sarana dan Prasarana Internal

4. Layanan Perkantoran

$$
\text { Laporan keuangan Bapas }
$$

mengemukakan tentang jumlah total dana yang diterima dan diengkapi dengan sejumlah Kegiatan beserta jumah biayanya sesuai dengan tahun anggaran.

Terdapat aplikasi khusus di bagian keuangan untuk dapat menjalankan tugas dan fungsi sebagaimana seharusnya, yaitu aplikasi RKA-KL yang digunakan untuk menyusun anggaran setiap tahunnya, SAIBA untuk melakukan rekap data terhadap pemasukan dan pengeluaran anggaran, GPP digunakan untuk penyusunan dan pengolahan gaji karyawan, SAS yang merupakan aplikasi sehari-hari dan digunakan untuk mengajukan pembayaran, pencatatan pengeluaran, surat perintah pembayaran, dan membuat laporan pertanggung jawaban.

\section{DAFTAR PUSTAKA}

Anonim. Penganggaran Dana. http://library.binus.ac.id/eColls/eThes isdoc/Bab2/Bab\%202 $09 \quad$ 163.pdf Diakses pada 10 Juli 2019.
Gunardi, Yenny. (2015). Alur Perencanaan dan Penganggaran.

https://docplayer.info/205853

Alur-perencanaan-dan-penganggaran.html Diakses pada 9 Juli 2019.

Handayani. (2007). Widyatama.

https://repository.widyatama.ac.id/x mlui/bit-

stream/handle/123456789/5439/

Bab\%202.df? sequence $=9$ Diakses pada 2 Juli 2019.

Hikmah, N. (2015). Pengaruh Kapasitas Sumber Daya Manusia, Perencanaan Anggaran. Jurnal Universitas Muhammadiyah

Mardiasmo. (2002). Akuntansi Sektor Publik. Yogyakarta: Andi Yogyakarta.

Pemerintah Indonesia. 2013. UndangUndang Republik Indonesia Nomor 17 Tahun 2003 tentang Keuangan Negara. Lembaran Negara Republik Indonesia Nomor 4286. Jakarta : Sekretariat Negara.

Puspita. (2013).

https://repository.widyatama.ac.id/x mlui/bitstream/handle/123456789/ 7886/Bab\%202. df?sequence $=10$ Diakses pada 10 Juli 2019.

Rachmasari, Yesi. Nulhaqim, Soni A. Apsari, Nurliana Cipta. (2016). Strategi

Fundraising: Konsep dan Implementasi. Bandung: Unpad Press.

Rahman, Saipul. (2013). Sistem Penganggaran Pemerintah. Universitas Brawijaya.

Sriana. Budgeting atau Anggaran. Universitas Mataram. 